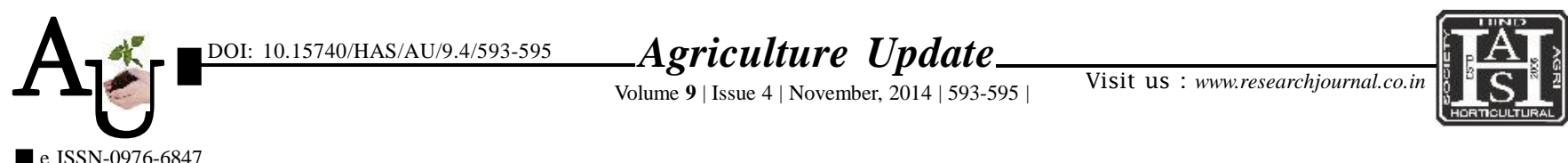

Research Note

\title{
Constraints faced by plum growers in production and marketing and suggestion made by them in district Poonch of Jammu and Kashmir
}

\author{
NEERJA SHARMA, SANJAY KHAR, S.S. JAMWAL AND RAJU GUPTA
}

Article Chronicle :

SUMMARY : The study was carried out to find out the constraints faced by the plum growers of Poonch area in production and marketing of the produce and the suggestions made by them to overcome the problems. Two tehsils, Mandi and Surankot of district Poonch were selected, from each tehsil five villages and from these five villages fifty respondents were selected for the study. The findings of the study revealed that fluctuation in market prices was the major problem which accounted for 90 per cent, high commission charges accounted for 80 per cent followed by irrigation i.e. scarcity of water in summer (78\%), non - availability of transport facility in time (76\%), non - availability of labour in time (70\%), high cost of fertilizers (64\%), non - availability of quality planting material $(60 \%)$ and fertilizers in time $(58 \%)$ and non - availability of good packing material (52\%). To overcome these problems suggestions were made them. They suggested transport facility in time, good quality packing material be available at low cost, availability of mechanical grading and packing facility, export facility outside the district, knowledge regarding pruning and production technology, facility provided for processing of fruits and cold storage van for their transportation.

KEY WoRdS:

Plum, Production,

How to cite this article : Sharma, Neerja, Khar, Sanjay, Jamwal, S.S. and Gupta, Raju (2014). Constraints faced by Marketing,

Constraints,

Suggestions Agric. Update, 9(4): 593-595.

Author for correspondence :

SANJAY KHAR

Krishi Vigyan Kendra

(SKAUST-J) POONCH (J\&K)

INDIA

Email: sanjaykhar2007

@ gmail.com

See end of the article for authors' affiliations 